\section{Facile/LigFerv: Água Quente em Três Segundos, Trinta Anos de Processo Empreendedor}

\author{
Facile/LigFerv: Hot Water in Three Seconds, Thirty Years of Entrepreneurial \\ Process
}

Disciplina: Empreendedorismo, Marketing

Temática: Processo Empreendedor, Modelo de Negócio

Setor de atividade: Varejo, Eletrodomésticos

Região: Minas Gerais/Brasil
João Paulo Moreira Silva ${ }^{1}$ Liliane de Oliveira Guimarães ${ }^{1}$ [ José Márcio de Castro ${ }^{1}$

\title{
INTRODUÇÃO
}

Dia de São José, 19 de março. Reza a crença popular, principalmente no nordeste do Brasil, que, se chover nesse dia, a colheita será farta. No interior de Minas Gerais, significa a enchente das goiabas. A chuva do dia 19 derruba as goiabas maduras, inundando o chão com a fruta cheirosa. São as "águas de março fechando o verão", já cantava Tom Jobim. Nilson pensava nas lendas que cercam o dia 19 de março. Esse dia de 2020 seria lembrado por outras razóes bem mais concretas, meditava Nilson sentado em frente ao computador, mas sem prestar atenção na tela. $\mathrm{O}$ prefeito de Belo Horizonte havia decretado, para o dia seguinte, o início do isolamento social. Somente serviços essenciais seriam mantidos abertos. Conter o avanço da contaminação pelo novo coronavírus na população e evitar sobrecarregar

1. Pontifícia Universidade Católica de Minas Gerais, Programa de Pós-graduação em Administração, Belo Horizonte, MG, Brasil.

Como citar: Silva, J. P. M., Guimarães, L. de O., \& Castro, J. M. de. (2021). Facile/LigFerv: Água quente em três segundos, trinta anos de processo empreendedor. Revista de Administração Contemporânea 25(spe), e200221. https://doi.org/10.1590/1982-7849rac2021200221.por os equipamentos hospitalares eram os objetivos de decisão táo radical. $\mathrm{O}$ mundo todo passava por isso.

Sentia-se perdido, sem clareza quanto aos impactos da pandemia nas pessoas, no sistema de saúde, na economia, nos negócios. Tudo muito confuso ainda. Pensou no produto LigFerv, na empresa Faciletec, no processo de aceleraçáo do negócio. Tanto esforço e trabalho no ano anterior, rememorou. Muito investimento na certificaçáo do produto e profissionalização da empresa, o novo modelo de negócio planejado e a proposta de adoção de um sistema de comercialização inovador. E agora essa situação inusitada, sem precedentes. Os prognósticos econômicos sinalizavam para a pior recessão desde 1929.

Classificaçāo JEL: A20, L66, M31 Editor-chefe: Wesley Mendes-Da-Silva (Fundação Getulio Vargas, EAESP, Brasil) Editora Associada: Paula C. P. de S. Chimenti (Universidade Federal do Rio de Janeiro, COPPEAD, Brasil) (1) Editor Convidado: Leonardo Marques (Universidade Federal do Rio de Janeiro, COPPEAD, Brasil) (10) Pareceristas: Luis Antonio da Rocha Dib (Universidade Federal do Rio de Janeiro, Brasil) Clarice Kogut (Universidade Federal do Rio de Janeiro, Brasil)

Relatório de Revisāo por Pares: A disponibilização do Relatório de Revisão por Pares não foi autorizada pelos revisores. Recebido: 14/07/2020 Última versão recebida em: 03/12/2020
Aceite em: 07/12/2020

\begin{tabular}{|c|c|c|c|c|c|c|c|c|c|}
\hline & 1 & 2 & 3 & 4 & 5 & 6 & 7 & 8 & 9 \\
\hline $1^{a}$ rodada & 2 & (x) & $\stackrel{9}{2}$ & & & & & & \\
\hline $2^{a}$ rodada & 2 & & & & & & & & \\
\hline $3^{a}$ rodada & $\stackrel{9}{2}$ & & & & & & & & \\
\hline
\end{tabular}


Suposiçóes de queda no produto interno bruto (PIB) da ordem de $5 \%$ eram ainda otimistas. Imerso nessa miríade de pensamentos, ouve Helena chamar: "Pai, o Márcio está dizendo boa tarde". Pai e filha haviam combinado uma chamada por vídeo com Márcio, mentor, que os havia acompanhado no projeto de aceleração da empresa no ano anterior para discutir a situação.

Pego no susto, Nilson diz: "Opa! Tudo beleza?" Aquele cumprimento soara simplesmente ridículo.

\section{A TRADIÇÃO DO CAFÉ}

$\mathrm{O}$ ato de beber café pela manhã é tradição para grande parte dos brasileiros. Entretanto, a família de Nilson tinha um ritual especial. Aos domingos, o primeiro dos cinco membros da família a se levantar tinha de fazer o café e levar uma xícara para os que ainda dormiam. Nilson não sabe se todos compartilhavam do seu pensamento, mas confessa que tinha muita preguiça de se levantar para coar o café - seu, dos pais e das duas irmãs.

Por causa disso, o despertador de corda da família acabou tendo outra finalidade, que Nilson conta de forma simples: "Aproveitando o movimento da corda do relógio, uma corda de náilon era enrolada, puxando um arame, ligando um contato numa resistência de chuveiro que ficava dentro de um copo de maionese. A água fervia instantaneamente". Por fim, a água passava por dentro de um tubo, obtido no laboratório da escola, e caía em um coador de pano que preparava cerca de $500 \mathrm{~mL}$ de café. A quantidade era suficiente para servir todos da casa, "e eu ficava muito tranquilo", ressalta o inventor do "relógio que coava café".

Seu invento, premiado em feiras de ciências escolares no início da década de 1970, acompanhou Nilson até sua vida adulta. Já na faculdade, enquanto cursava Engenharia Eletrônica e de Telecomunicações, fez amizade com Airton. Seu novo amigo, tal como Nilson, era dado a invençóes e tentava criar um miniebulidor para ferver pequenas quantidades de água. Os dois se uniram e, compartilhando ideias, desenvolveram um fervedor de água instantâneo.

No entanto, por trabalharem na ideia do fervedor apenas nos horários vagos do trabalho e dos estudos, a concretizaçáa do projeto foi lenta. Em 1982, Nilson se tornou professor universitário, iniciando uma vida dupla entre a docência e a empresa que o acompanharia nas próximas três décadas. Após algumas tentativas, a dupla desenvolveu um modelo robusto, feito de plástico moldado. Esse modelo foi batizado de Liga-Ferve e a sua operaçáo era simples: ao ligar de um botão, tem-se água fervente em três segundos. O limite do reservatório comportava até $1 \mathrm{~L}$ de água, e o gasto de energia elétrica era mínimo - 1.000 xícaras de café/mês representam acréscimo de $\mathrm{R} \$ 3,20$ na conta de energia. Já de posse do nome, a dupla de inventores deu início ao primeiro processo de patenteamento do produto que, por razóes legais, teria seu nome comercial modificado para LigFerv. A inovação do produto, sem similares no mercado, consistia em ferver, em três segundos, a água a ser usada em bebidas quentes.

Por meio da rede de relaçóes possibilitadas pela universidade, Nilson e Airton encontraram, em 1990, um parceiro para auxiliar na produçáo do projeto inovador. Esse parceiro era a MC Indústrias, uma empresa de médio porte localizada na regiáo metropolitana de Belo Horizonte. A MC, que já atuava no segmento de telecomunicaçóes e automação industrial, assumiu a responsabilidade de se aventurar também em eletrodomésticos. Segundo Nilson, "a filosofia da MC era criar uma espécie de incubadora de empresas". Além de terem à disposição uma variedade de recursos, como espaço físico, estrutura administrativa, máquinas e equipamentos, os inventores do LigFerv obtiveram uma linha de crédito - US\$ 150.000,00 - de um banco de desenvolvimento, que foi quitado em um ano de produção e vendas do produto. Uma das intervençóes da quase incubadora foi a definição do processo de patenteamento do projeto, uma vez que a patente requisitada anteriormente pelos inventores estava incompleta.

No período de parceria com a MC, pesquisas de mercado foram realizadas, houve reformulações no design, além do investimento em ferramentaria e na linha de produção. Entre 1994 e 1995, o ambiente econômico afetou diretamente os investimentos da empresa-mãe na produção do LigFerv. Sabendo da necessidade de mais investimentos em marketing e desenvolvimento de canais de comercialização e das dificuldades financeiras da $\mathrm{MC}$, a parceria se dissolveu. Dificuldades na rotina culminaram na saída de Airton do projeto, o que desaguou na criação da Facile em 1998, uma empresa já independente da MC. A primeira fábrica da empresa seria em Poços de Caldas, local onde Nilson estava morando à época com esposa e filhas, atendendo à nomeação da universidade.

\section{A FACILE: CRIAÇÃO, VENDAS E "SUCESSO"}

Em 1999, um ano depois de se instalar em Poços de Caldas, Nilson foi para os Estados Unidos, deixando na cidade uma pessoa responsável pela gestão da fábrica e, em Belo Horizonte, o pai, que coordenava a comercialização do produto. $\mathrm{O}$ pai, sócio da empresa, e que durante a "incubação" na MC já havia vendido um carro e comprado vários LigFerv para revender ao cliente final, agora era o único responsável pela comercialização do produto. 
Em 2000, Nilson estava de volta ao Brasil e a Belo Horizonte. $\mathrm{O}$ produto remodelado, com o design que permanece até hoje, teve início em 2000 e só foi concluído em 2005, em virtude de as reunióes de planejamento serem feitas em horários de folga e, no geral, à noite, nos intervalos das atividades docentes e com a participação de um designer, um estagiário e o empresário responsável pela fabricação dos moldes para injeção das peças em plástico do produto, também professor na universidade. Naquele momento, Nilson começava a se preocupar com a certificaçâo do produto no Instituto Nacional de Metrologia, Qualidade e Tecnologia (Inmetro). Apesar de considerar a ideia de certificar o produto antes de colocá-lo à venda no mercado, a legislaçáo brasileira, à época, náo previa essa obrigatoriedade. Além disso, havia o custo para a aquisiçáo da certificação, de aproximadamente $\mathrm{R} \$ 40.000,00$ para cada teste realizado. Mas Nilson estava confiante da segurança e durabilidade de seu produto, afinal, como sempre repetia, "o cara comprou, gostou, ele nunca mais compra outro, porque não estraga!”

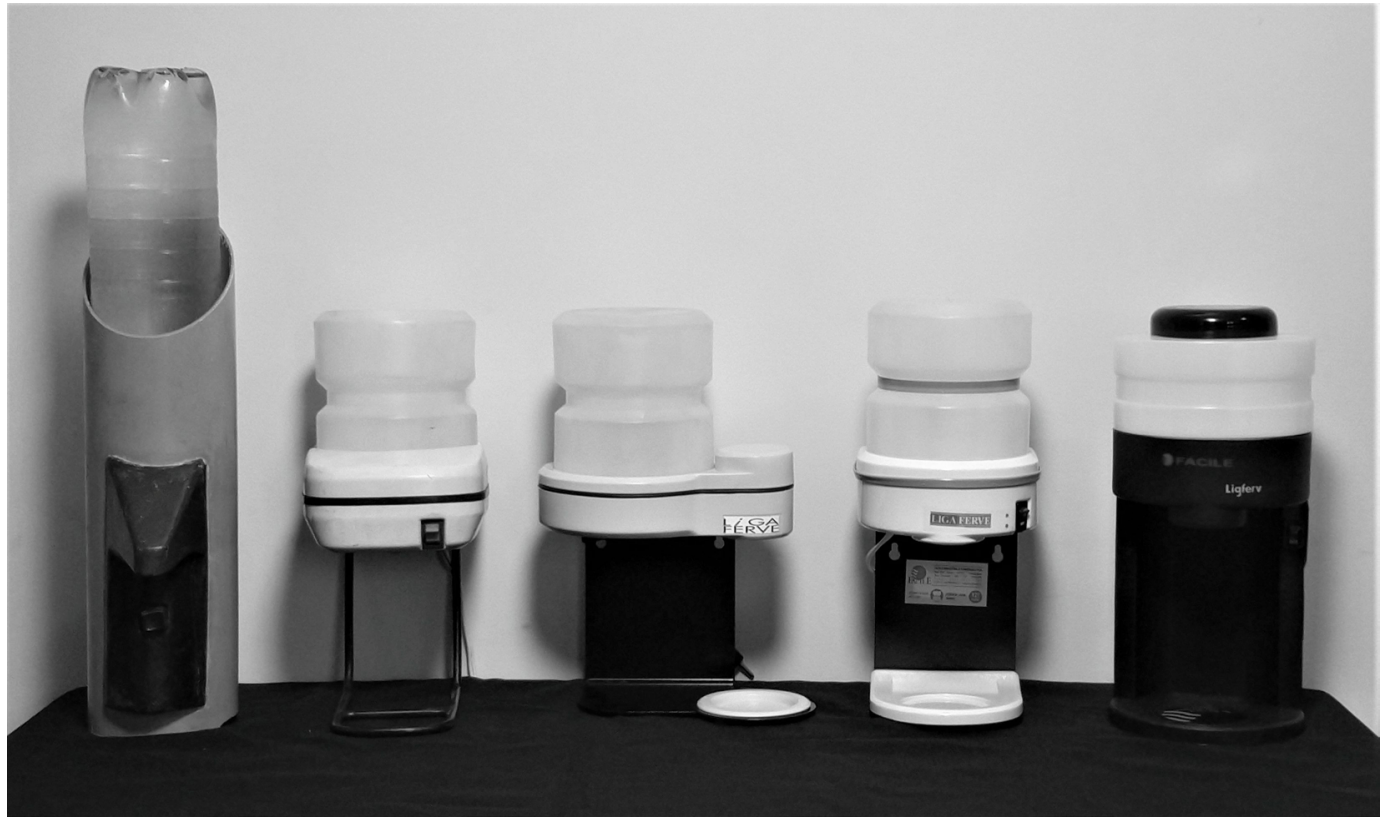

Figura 1. Evolução dos modelos LigFerv (1990-2006).

Fonte: Foto fornecida pelo empreendedor entrevistado.

Dessa forma, Nilson decidiu adiar a certificação e, em 2006, a empresa estava pronta para profissionalizar a produção e comercialização do LigFerv. A forma de trabalho era simples: enquanto Nilson gerenciava as questóes técnicas do produto e as finanças da empresa, seu pai auxiliava nas vendas, além do primo que atuava na produção. $\mathrm{O}$ reconhecimento sobre o valor do produto não demorou a chegar. Nilson recebeu sondagens de grandes empresas do setor de eletrodomésticos e jura que uma delas copiou até o seu slogan: "Água fervente em três segundos: economize tempo, economize energia e economize dinheiro". O relativo sucesso não pararia por aí. O LigFerv chegou a ser demonstrado ao vivo no programa culinário da Palmirinha, exibido pela TV Gazeta no estado de São Paulo. Em uma das feiras da qual participou, apareceu em uma reportagem da TV Globo. Com bom humor, Nilson comenta: "Dura sete segundos a notícia. E três segundos são fervendo água". Em virtude dessa exposição, no dia seguinte, Nilson vendeu mais de 1.000 máquinas, seis vezes a quantidade vendida em todos os dias de feira no ano anterior.

Mas as notícias positivas parariam por aí. Pouco tempo depois, em 2012, uma resolução do Inmetro tornaria obrigatória a certificação para produtos como o LigFerv. Mas a falta de expectativa para obter a certificação não desanimou Nilson. Mesmo com as dificuldades, a Facile prosseguiu e chegou a comercializar mais de 23.000 unidades do produto desde 2006. O bom retrospecto de vendas, inclusive, foi crucial para a seleção de Nilson e da Facile, em 2018, ao ProTEC, o programa de aceleraçáo de negócios da maior universidade privada do estado de Minas Gerais. 


\section{PRONTO PARA DECOLAR}

Nilson considera que a profissionalização da Facile, mesmo operando há tanto tempo, tenha vindo apenas com a entrada da empresa no programa de aceleração ProTEC. A disputa pela participação no programa foi acirrada e Nilson entrou na disputa com outras 87 empresas. Entre elas, ideias e projetos um pouco mais estabelecidos, que competiam pela oportunidade de trabalhar por 12 meses em um coworking da capital mineira e ter acesso a investimentos financeiros e recursos humanos, além de mentoria de uma consultoria designada pelo programa de aceleraçáo.

Buscando competir com as outras empresas, majoritariamente formadas por empresas de plataformas de serviço, criou a Faciletec, a organização que passaria a coordenar o LigFerv. Os sócios? Ele e as duas filhas. Conforme destaca Nilson, o seu pensamento era muito bem definido: a Faciletec entraria no programa de aceleraçáo para escalar a produção e venda do LigFerv. O tão buscado sucesso comercial do produto possibilitaria, então, a construção de toda uma família de produtos eletrodomésticos, tão inovadores quanto o primeiro. Entre esses produtos estavam versôes inovadoras de uma secadora de roupas e um LigFerv ao contrário, que gelaria bebidas instantaneamente. Ao final, o desempenho da Faciletec no programa superou quaisquer expectativas, pois a empresa terminou entre as 12 finalistas do programa de aceleraçáo.

Além da colocação da empresa - que rendeu ao todo $\mathrm{R} \$ 100.000,00$ em investimentos à Faciletec em troca de $6 \%$ da parte societária para a universidade -, os principais ganhos vieram na forma de conhecimentos em gestão que transformaram a forma como Nilson enxergava a própria empresa. As mentorias mostraram ao empresário que a Facile e a Faciletec ainda operavam sobre conceitos amadores. Dessa forma, as mentorias desencadearam na Faciletec significativas transformaçóes, como a criação de contratos para formalizar as transaçōes da empresa e o estabelecimento de processos organizados para marketing e vendas.
Os conselhos do mentor Márcio, que acompanhou todo o processo de aceleração da empresa fornecendo mentoria, abrangeram três questóes centrais para o futuro do LigFerv: (a) a necessidade de certificar o produto no Inmetro; (b) a obtenção de uma fábrica regularizada nos padrões da International Organization for Standardization (ISO) 9001 para a certificaçấo da produção; e (c) a possibilidade de encontrar um modelo de receita recorrente para a Faciletec, uma vez que o LigFerv tem vida útil muito longa.

A possibilidade de conseguir uma receita recorrente por meio de outro modelo de negócios deixou Nilson animado. $\mathrm{O}$ empresário já vislumbrava uma parceria com marcas que comercializam café tipo gourmet e a criação de um clube de assinatura, pelo qual o assinante receberia em sua casa o LigFerv e também, mensalmente, os cafés para degustação. Caso o assinante cancelasse sua assinatura, a máquina seria recolhida, uma vez que o cliente não teria mais o direito de uso do aparelho. Para Nilson, essa era uma saída para o "bom problema" que tinha, já que o LigFerv tem vida útil longa e "quem tem não fica sem".

\section{ANOS DE NOVIDADE}

Os números que Nilson apresentou para concorrer ao edital do ProTEC foram de grande auxílio para permitir a aprovaçáo dos jurados. Primeiramente, a quantidade de funcionalidades que o produto possuía era extensa: (a) uso doméstico e empresarial para preparo de bebidas quentes (chá, café, leite, entre outras) e comidas instantâneas (sopas, lámen); (b) higiene pessoal - água quente para atividades de manicure, barba e limpeza de pele; (c) área profissional - na Odontologia, em prótese dentária, para acelerar a polimerização de acrílicos e a plastificação de ceras e godivas; na Fisioterapia, para preparo de bolsas e compressas de água quente. $\mathrm{O}$ preço do LigFerv diretamente na loja virtual é de R\$197,00 e existem opçóes na voltagem $127 \mathrm{~V}$ ou 220 V (no Apêndice, a Figura A1 mostra o design atual do produto). Na Figura 2 pode-se visualizar, em unidades, o fluxo de vendas da LigFerv entre 2006 e 2018.

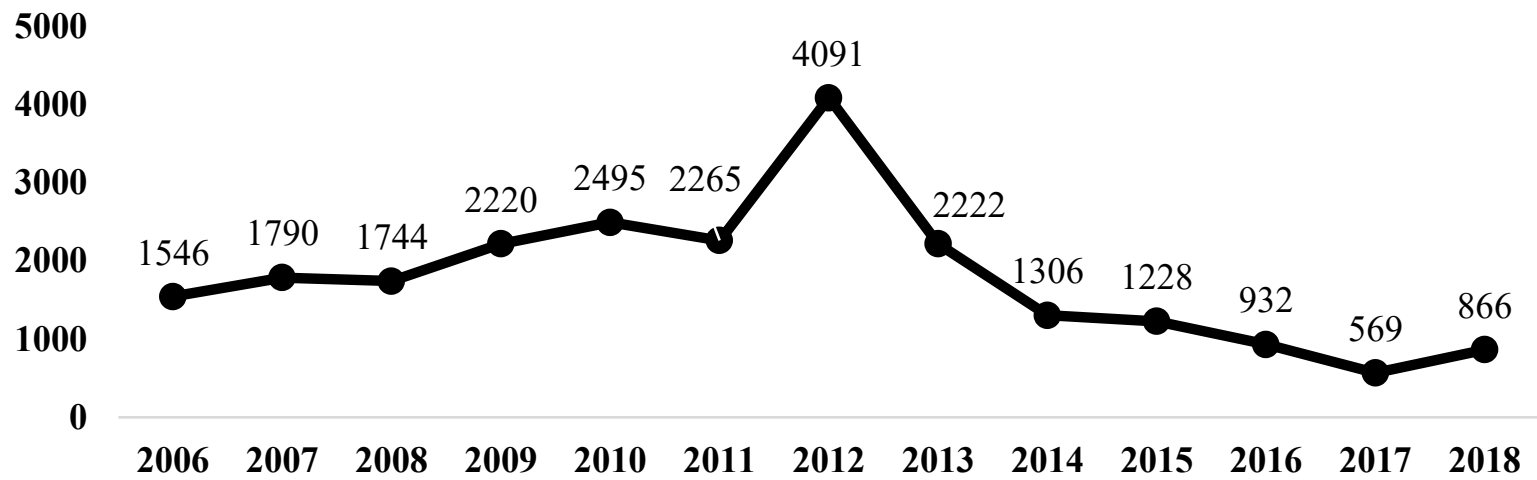

Figura 2. Vendas de LigFerv (2006-2018).

Fonte: Dados da pesquisa. 
Durante as etapas classificatórias do programa de aceleração, a filha Helena iniciou uma pesquisa com os clientes que já haviam adquirido o produto. Identificou-se que a ampla maioria dos respondentes utiliza o produto no trabalho $(55,4 \%)$ ou em casa $(36,5 \%)$ e que a maior parte o usa para o preparo de bebidas quentes, como chás $(66,2 \%)$, cappuccinos $(59,5 \%)$, café coado $(43,2 \%)$, café solúvel $(40,5 \%)$, sendo também amplamente empregado na prática da Odontologia (27\%).

Além disso, os resultados surpreenderam a todos ao se verificar que a empresa - e o produto - náo possuía clientes detratores. A grande maioria de sua amostra havia conhecido o produto por meio de indicaçóes $(59,4 \%)$ e apenas pequena parcela havia conhecido por buscadores na internet $(8,7 \%)$.

\section{MERCADO DE ELETRODOMÉSTICOS E ELETROPORTÁTEIS}

No setor de eletrodomésticos brasileiro, altamente influenciado pelo contexto social, político e econômico, as taxas de crescimento nos últimos anos sofreram duros golpes, devido à crise econômica, à greve dos caminhoneiros, à incerteza com as eleiçóes presidenciais e, mais recentemente, à queda de confiança. Tanto em 2018 quanto em 2019, o crescimento foi de $5 \%$, metade do previsto pelo próprio setor ${ }^{1}$. Ressalta-se, porém, que o cenário negativo acabou por elevar a demanda reprimida, deixando um potencial de crescimento a ser explorado nos próximos anos.

Os eletroportáteis, com valores menores quando comparados aos eletrodomésticos, demonstram evoluçáo branda, mas consistente ${ }^{1}$. Entretanto, a situação atual não é confortável e a recuperação tende a ser lenta. Em abril, as vendas no comércio varejista caíram $16,8 \%$, o pior resultado desde o início da série histórica. Mas o isolamento social e a permanência em casa, cumpridos por parte da população brasileira, também impediram uma queda maior por meio das vendas do varejo on-line. No primeiro trimestre de 2020, o varejo físico registrou retração em extensa gama de eletroeletrônicos, mas foi sustentado pelo crescimento da sua contraparte on-line. As cafeteiras, por exemplo, tiveram crescimento de $86,1 \%$ no período com as vendas por meio de canais virtuais.

A Figura 3 demonstra as variaçóes de desempenho do setor de eletrodomésticos no Brasil no ano de 2020.

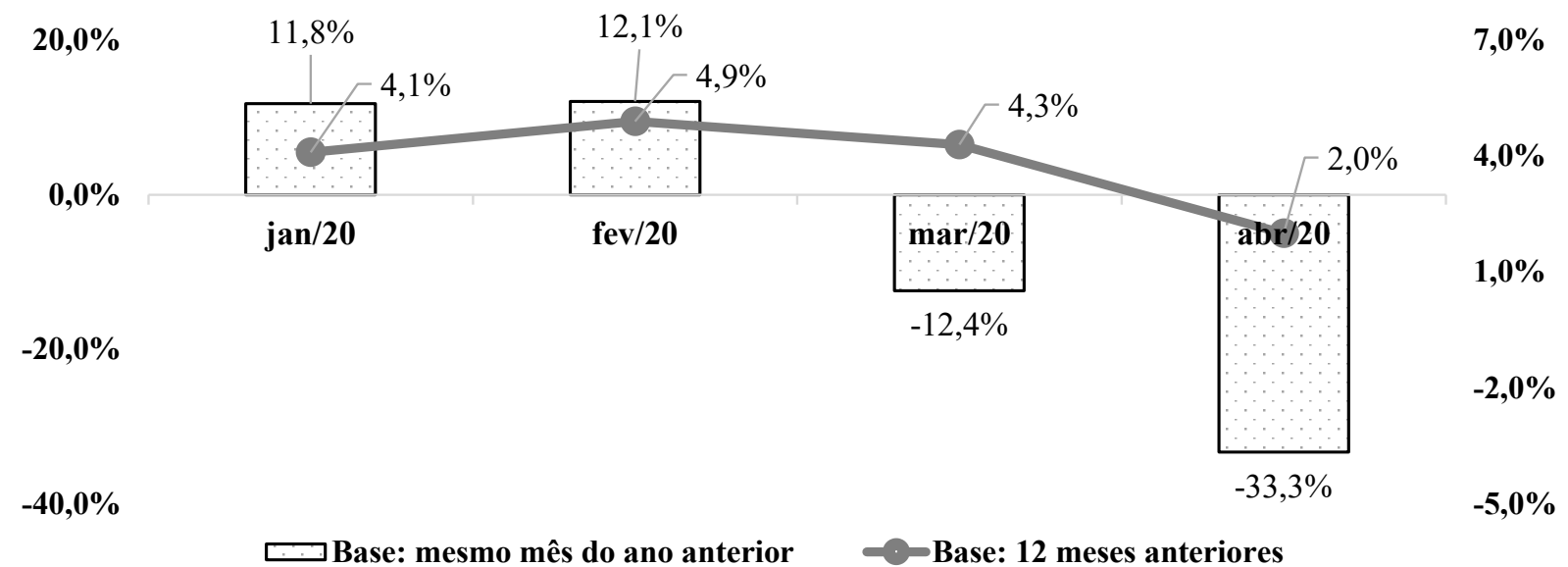

Figura 3. Volume de vendas de eletrodomésticos no comércio varejista - comparação mensal (\%).

Fonte: Agência IBGE Notícias (2020). Vendas no varejo variam -0,1\% em dezembro e acumulam alta de 1,8\% em 2019. Retrieved from https:// agenciadenoticias.ibge.gov.br/agencia-sala-de-imprensa/2013-agencia-de-noticias/releases/26856-vendas-no-varejo-variam-0-1-em-dezembro-e-acumulam-alta-de-1-8-em-2019

\section{MERCADO DE BEBIDAS QUENTES}

As bebidas quentes estão entre os tipos de bebidas mais consumidas no Brasil e no mundo. Na primeira posição, com aproximadamente 400 bilhôes de litros consumidos ao ano, está o chá. O café aparece em quinto lugar, com aproximadamente 200 bilhóes de litros consumidos ${ }^{2}$, e a expectativa era de consumo recorde da bebida no ano de 2020, de aproximadamente 166 milhóes de sacas em todo o mundo.
No Brasil, o consumo de café é predominante: o consumo per capita apresentou crescimento contínuo ao longo das últimas duas décadas e chega a $6,02 \mathrm{~kg} / \mathrm{ano}$, movimentando mais de $\mathrm{R} \$ 8,5$ bilhóes. Esses dados posicionam o país como um dos maiores produtores e consumidores de café do mundo. Além disso, as vendas do grão torrado e das cápsulas também são representativas. Em 2021, é esperado que o primeiro atinja $19 \%$ do volume de vendas no mercado nacional, enquanto o segundo obtenha $1,1 \%$ do volume total de vendas. $\mathrm{O}$ 
consumo de café premium já responde por cerca de $10 \%$ do mercado $^{2}$.

A Figura 4 exibe a evolução do consumo per capita no Brasil entre 1996 e 2016.
O chá, por outro lado, tem menos adesão em território nacional e o país não figura nem entre os 15 maiores consumidores da bebida. Por outro lado, a versatilidade do chá é um diferencial, uma vez que a bebida pode ser utilizada para hidratação, refresco, indulgência ou fonte de energia funcional ${ }^{3}$.

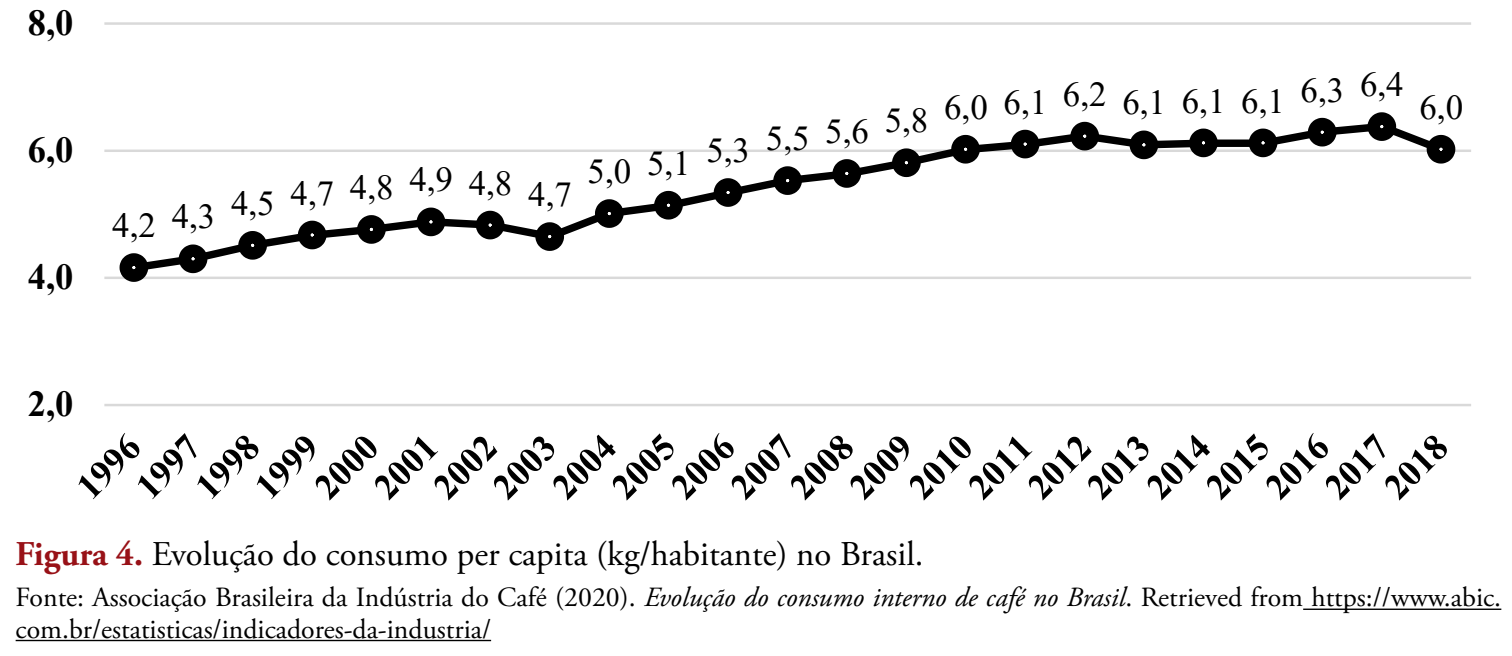

\section{PANDEMIA E MUDANÇAS DE CONSUMO}

A pandemia do COVID-19 transformou a rotina de muitas empresas e cidadáos ao redor do mundo. No Brasil, o primeiro trimestre de 2020 trouxe um recuo do PIB de 1,5\%, conforme Figura 5.

Essa queda respondeu pela diminuição de $60 \%$, na média, do faturamento de $89 \%$ das pequenas empresas do país. Apesar disso, as dificuldades atreladas à pandemia exigiram uma guinada digital, uma vez que aproximadamente $30 \%$ das pequenas empresas aderiram a medidas como vendas on-line por meio de redes sociais. Mais especificamente, 11,7\% iniciaram o gerenciamento de suas contas bancárias por meio de aplicativos das instituiçóes financeiras e outras 7,5\% começaram a realizar vendas por aplicativos móveis ${ }^{4}$.

Uma projeção de mudança de comportamento foi identificada também nos consumidores. Com a expectativa de redução da renda, os gastos dos brasileiros se voltaram para o consumo de itens para o lar. Em abril, entre 32 categorias incluindo produtos e serviços de diferentes naturezas-, os únicos produtos previstos para aumento de consumo pelas famílias brasileiras eram os de mercearia e materiais de limpeza ${ }^{5}$. $\mathrm{O}$ ato de comprar on-line também descortinou novos horizontes para as organizaçôes. No varejo, a situação de algumas empresas é de aumento expressivo no número de vendas, devido às operaçóes feitas on-line, mas com perdas nas margens de lucro, consequência da manutenção de suas estruturas físicas.

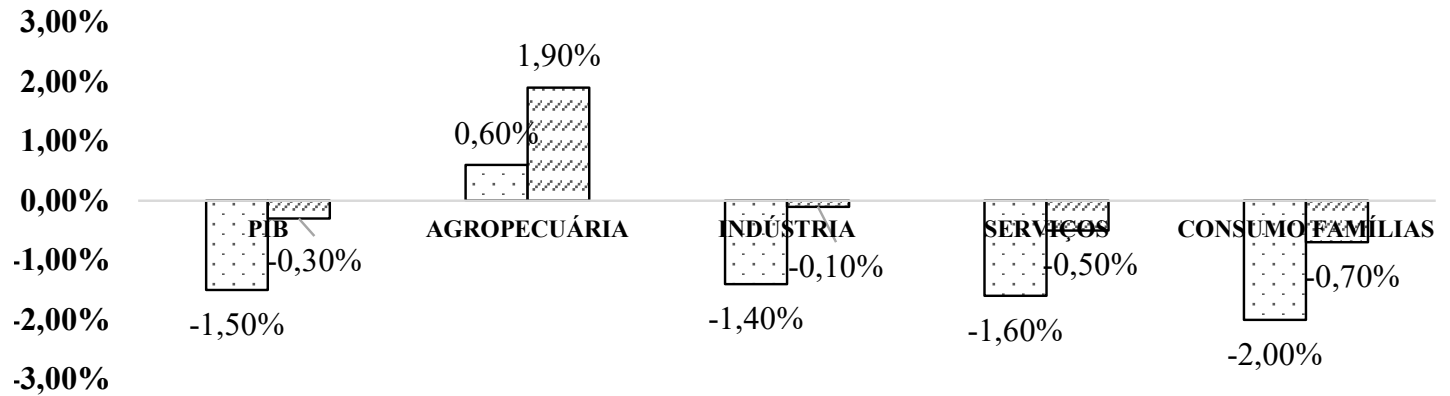

$\square$ Trimestre / trimestre imediatamente anterior (com ajuste sazonal)

a Trimestre / mesmo trimestre do ano anterior (sem ajuste sazonal)

Figura 5. Indicadores econômicos (PIB) - $1^{\circ}$ trimestre de 2020.

Fonte: Agência IBGE Notícias (2020). PIB cai 1,5\% no $1^{\circ}$ trimestre de 2020. Retrieved from https://agenciadenoticias.ibge.gov.br/ agencia-sala-de-imprensa/2013-agencia-de-noticias/releases/27837-pib-cai-1-5-no-1-trimestre-de-2020 


\section{E NO MEIO DO CAMINHO TINHA UM VÍRUS}

Assim que cumprimentou o mentor Márcio na videochamada, a conexão caiu. Enquanto Helena refazia a ligação, Nilson ainda pensou, enquanto rabiscava na agenda de papel de 2012 que estava na mesa: o ano de 2020 se iniciara promissor para ele e a Faciletec. Com os $\mathrm{R} \$ 100.000,00$ conquistados no ProTEC, o empresário separou 18 fervedores de água (LigFerv) que já haviam passado por um pré-teste, para enviá-los ao Rio Grande do Sul, onde iriam efetuar os testes finais para certificação. Enquanto isso, um dos amigos que o auxiliaram na elaboração do atual modelo do LigFerv já estava adequando os processos de sua fábrica para obter a ISO 9001 para produzirem o fervedor certificado. Além disso, começara a prospectar também algumas latas de alumínio estilizadas para acondicionar o café a ser entregue mensalmente para os futuros assinantes com o LigFerv em sistema de comodato. A proposta previa um modelo de comercialização por assinatura em todo o país. Para enriquecer a experiência do consumidor na degustaçáo do café, a cada mês o modelo de negócio pressupunha o envio de um tipo de café gourmet, variando por regiáo do Brasil.

Pensava nisso quando Márcio retornou a videochamada. $\mathrm{O}$ modelo de negócio baseado em assinaturas seria viável para seu produto pós-pandemia? $\mathrm{O}$ planejado no ano anterior no processo de aceleraçáo ainda faria sentido no "novo normal"? Ou o fabrico e a venda do aparelho no formato tradicional ainda deveriam prevalecer? Seria estratégico conjugar um modelo híbrido, venda tradicional e assinatura? Nesse momento seu sentimento era de que estava sempre recomeçando, sempre no estágio inicial do seu processo empreendedor.

\section{NOTAS}

1. Mercado e Consumo (2020, January). Setor de eletroeletrônicos cresce 5\% em 2019. Retrieved from https://www.mercadoeconsumo.com.br/2020/01/29/ setor-de-eletroeletronicos-cresce-5-em-2019/

2. Euromonitor Research (2017, December). Ranked: Top 15 tea-drinking countries. Retrieved from https://blog. euromonitor.com/ranked-top-15-tea-drinking-countries/

3. Euromonitor International (2019). Tea in Brazil. Retrieved from https://www.euromonitor.com/tea-in-brazil/report

4. Serviço Brasileiro de Apoio às Micro e Pequenas Empresas (2020, May). O impacto da pandemia de coronavírus nos pequenos negócios. Retrieved from https://m.sebrae.com. br/sites/PortalSebrae/artigos/o-impacto-da-pandemia-decoronavirus-nos-pequenos-negocios, 192da538c1be1710V gnVCM1000004c00210aRCRD

5. Charm, T., Grimmelt, A., Kim, H., Robinson, K., Lu, N., Mayank, Ortega, M., Staack, Y., \& Yamakawa, N. (2020, October). Consumer sentiment and behavior continue to reflect the uncertainty of the COVID-19 crisis. McKinsey \& Company. Retrieved from https://www.mckinsey.com/ business-functions/marketing-and-sales/our-insights/aglobal-view-of-how-consumer-behavior-is-changing-amidcovid-19 


\section{RESUMO}

Este caso de ensino objetiva discutir um processo empreendedor envolvendo a trajetória de um produto inovador ao longo de trinta anos até culminar em um significativo evento de mudança do modelo de negócio da empresa em meio à crise desencadeada pela pandemia do novo coronavírus. $\mathrm{O}$ caso oferece oportunidades para a discussáo de teorias relacionadas ao processo empreendedor - lógicas causation e effectuation. Além disso, no curso da trajetória recente, em que a empresa é selecionada para um programa de aceleração, emerge uma possível mudança do modelo de negócio. Relatado a partir da ótica do fundador, mas também apoiado em materiais de fontes secundárias, o caso apresenta a trajetória da empresa Facile. A estratégia de ensino consiste em possibilitar ao aluno aprender, em primeiro lugar, sobre a tomada de decisão e açáo do empreendedor emulando ao longo do caso transiçóes entre as lógicas causation e effectuation para explicar tal comportamento. Posteriormente, o caso indaga sobre possíveis alternativas de mudança do modelo de negócio para a empresa após o programa de aceleração, quando os alunos poderão identificar alternativas mais adequadas, em face tanto das competências da empresa quanto, náo menos importante, da pandemia que alterou o comportamento dos clientes e dos empreendedores.

Palavras-chave: processo empreendedor; effectuation; modelo de negócio; pandemia.

\section{OBJETIVOS DE APRENDIZAGEM}

O presente caso foi desenvolvido para utilização em situaçóes de ensino em cursos de graduaçáo e pósgraduação lato sensu nas disciplinas Empreendedorismo e Inovação, Estratégia, Modelos de Negócios, Marketing e demais disciplinas cujos objetivos voltarem-se para processo de criação e desenvolvimento de negócios inovadores. Pode também ser utilizado em cursos livres de formação empreendedora, como os oferecidos pelo Sebrae, incubadoras e aceleradoras de empresas.

A expectativa é de que os estudantes possam desenvolver competências para avaliar mercados e modelos de negócio, aperfeiçoando suas capacidades na análise de cenários e estratégias mercadológicas.

Os objetivos didáticos, portanto, são: (a) compreender o processo empreendedor a partir de lógicas diferentes de análise: effectuation e causation; (b) analisar como o processo empreendedor pode ser fortalecido por mecanismos de incubação ou aceleraçáo de negócios; (c) analisar como a participação em um processo de aceleração pode gerar revisão

\section{ABSTRACT}

This teaching case aims to discuss an entrepreneurial process involving the trajectory of an innovative product over thirty years until culminating in a significant event in the change of the company's business model in the midst of the crisis triggered by the pandemic of the new coronavirus. The case offers opportunities for discussing theories related to the entrepreneurial process - causation and effectuation logic. In addition, in the course of the recent trajectory, in which the company is selected for an acceleration program, a possible change in the business model emerges. Reported from the perspective of the founder, but also supported by materials from secondary sources, the case presents the trajectory of Facile. The teaching strategy consists in enabling the student to learn, first, about the entrepreneur's decision-making and action, emulating transitions between the causation and effectuation logic throughout the case to explain such behavior. Subsequently, the case inquires about possible alternatives for changing the business model for the company after the acceleration program, in which students will be able to identify more suitable alternatives in the face of both the company's skills and, not least, the pandemic that changed the behavior of customers and entrepreneurs.

Keywords: entrepreneurial process; effectuation; business model; pandemic. no modelo de negócio; (d) analisar como crises agudas e eventos imprevistos podem afetar a implementação de modelos de negócios planejados no processo de aceleraçáo.

A partir dos objetivos expostos, foram elaboradas as seguintes questóes:

Atividade inicial: Elabore um mapa mental e uma linha do tempo como síntese dos eventos do caso. Quais foram ou são os principais desafios durante a trajetória empreendedora?

1. Analise o processo empreendedor descrito no caso por meio das lógicas causation e effectuation.

2. Imagine-se no lugar de Márcio, o mentor de Nilson. Quais conselhos você daria a Nilson acerca do futuro da Faciletec?

3. Qual modelo de negócio deveria ser seguido pela Faciletec na venda de seu produto LigFerv? 


\section{PROTAGONISTA E FONTES DE INFORMAÇÃO}

O caso é apresentado a partir da história empreendedora do engenheiro Nilson de Figueiredo Filho, de sua experiência em um processo de aceleração, surpreendido nessa trajetória por um grave problema de saúde pública - a COVID-19. A crise, de proporçóes gigantescas, implicou isolamento social, suspensão de negócios, arrefecimento de transaçóes comerciais, desemprego e, no caso específico, paralisação do processo de certificação do produto, da fábrica e de readequação do modelo de negócio.

Os dados para a elaboração do caso foram obtidos por meio de vídeos, pitches, relatos de mídia, relatórios de pesquisas de mercado, portal da empresa, informes de mídia cedidos pelo protagonista, não apenas de aspectos históricos da empresa, mas também da documentação relativa ao processo de aceleração vivido no ano de 2019. Além dos dados documentais, foram realizadas entrevistas com o sócio fundador e a sócia proprietária, filha do protagonista.

\section{ORIENTAÇÃO DIDÁTICO-PEDAGÓGICA PARA DISCUSSÃO DO CASO}

Para que a discussão do caso seja mais profícua, recomenda-se que o professor realize discussão teórica prévia sobre o processo empreendedor - lógicas causation e effectuation - e, caso tenha interesse na realização da Questáo 3 - que figura como tarefa extra -, também exercite a temática de modelos de negócio. São leituras indicadas: Sarasvathy (2001), Sarasvathy e Dew (2005), DaSilva e Trkman (2014) e Osterwalder e Pigneur (2010).

Posteriormente à apresentação e discussão dos fundamentos teóricos, a ideia é que o professor organize a sala em três grupos e destine pelo menos 20 minutos para leitura caso os alunos não tenham efetuado a leitura previamente - $\mathrm{e}$ 25 minutos para a discussão das questôes do caso aos grupos.

Finalizada a discussão em pequenos grupos, o professor organiza a plenária, destinando 60 minutos para a consolidação das respostas pensadas para os desafios do caso. $\mathrm{O}$ encerramento da discussão em plenária deverá ser realizado nos 15 minutos restantes.

\section{Abertura da discussão}

Atividades iniciais: construindo a síntese do caso (25 minutos). Como forma de aquecimento para discussão do caso, sugerem-se duas atividades que iráo anteceder as questóes relativas ao caso:
A) Para a compreensão do caso de forma geral, recomenda-se que os alunos elaborem um mapa mental e uma linha do tempo, onde os eventos do caso poderão ser sintetizados. Inicialmente, para o mapa mental, sugere-se que os participantes respondam a perguntas como: Quais são os personagens principais do caso apresentado? Qual é o seu principal problema? Quais foram/são seus principais desafios durante a trajetória empreendedora? Em seguida, utilizando-se da linha do tempo, sugere-se que os alunos pontuem os eventos que considerarem críticos, assinalando-os até o momento de desfecho do caso. Buscando a contextualizaçáo da linha do tempo, alguns questionamentos podem ser utilizados, como: Levando-se em conta o processo empreendedor exposto, o que mudou ao longo do tempo? É possível perceber algum período de transiçáo? Caso positivo, o que mudou de um período para o outro? Como você imagina que o processo de tomada de decisão era realizado nos diferentes períodos de tempo?

B) Posteriormente, recomenda-se que o professor organize informaçōes, em um slide (exemplo: Figura A2, no Apêndice), sobre o mercado de assinaturas produtos/serviços comparado com o mercado tradicional de vendas de produtos e serviços, especificamente sobre o consumo de bebidas quentes. O objetivo é que os alunos visualizem informações pertinentes à análise do caso.

Questão 1 - Análise do processo empreendedor: lógicas causation e effectuation (60 minutos)

Os modelos tradicionais que se propóem a planejar e explicar o processo empreendedor baseiam-se em fases sequenciais planejadas (Hisrich, Peters, \& Shepherd, 2014). Essas etapas geralmente são constituídas pela identificação e avaliação da oportunidade, bem como pelo desenvolvimento, crescimento e gerenciamento da empresa, visando a prever resultados e numa perspectiva de mercado estável e perfeito (Bourry \& Teixeira, 2019). Esses modelos consideram que para o negócio ser bem-sucedido, deve-se desenvolver um planejamento, como, por exemplo, um plano de negócios.

Feger, Vieira e Chemim (2016) apresentaram um modelo com as etapas e atividades do processo de criaçáo de um empreendimento (Tabela 1 ).

Sarasvathy (2001) propôs uma nova perspectiva effectuation - para análise do empreendedorismo. Na sua avaliação, os modelos tradicionais de avaliação do processo empreendedor não são adequados à fase inicial do negócio. Em linhas gerais, a análise do processo de criação de uma empresa a partir da lógica effectuation parte do princípio de que, no seu processo decisório, o empreendedor considera três categorias que correspondem a um conjunto de meios: (a) quem eles são - diz respeito às suas próprias características, preferências e habilidades; (b) o que eles sabem - são os conhecimentos e informaçóes que eles possuem; (c) quem eles conhecem - ou seja, as redes sociais das quais fazem parte (Sarasvathy, 2001). 
Tabela 1. Etapas e atividades na criação de um empreendimento.

\begin{tabular}{|c|c|c|c|c|}
\hline Estágio & Iniciação & Preparação & Lançamento & Consolidaçãoo \\
\hline Atividades & $\begin{array}{l}\text { Identificação da oportunidade } \\
\text { de negócio } \\
\text { Reflexáo e desenvolvimento da } \\
\text { ideia de negócio } \\
\text { Decisão de criar o } \\
\text { empreendimento }\end{array}$ & $\begin{array}{l}\text { Elaboração do plano de } \\
\text { negócios } \\
\text { Conclusão da pesquisa de } \\
\text { marketing } \\
\text { Captação de recursos } \\
\text { Criação do time empresarial } \\
\text { (parceiros) } \\
\text { Registro da marca ou patente }\end{array}$ & $\begin{array}{l}\text { Trâmites legais } \\
\text { Dedicação integral ao } \\
\text { empreendimento } \\
\text { Organização de instalaçôes e } \\
\text { equipamentos } \\
\text { Desenvolvimento dos primeiros } \\
\text { produtos e serviços } \\
\text { Contratação de funcionários } \\
\text { Primeiras vendas }\end{array}$ & $\begin{array}{l}\text { Atividades de promoção e } \\
\text { marketing } \\
\text { Vendas } \\
\text { Alcance do ponto de equilíbrio } \\
\text { Planejamento formal } \\
\text { Gestão }\end{array}$ \\
\hline
\end{tabular}

Nota. Fonte: Feger, Vieira e Chemin (2016, p. 1043).

Tabela 2. Tomada de decisão nos processos de causation e effectuation.

\begin{tabular}{|c|c|}
\hline Causation & Effectuation \\
\hline $\begin{array}{l}\text { Um determinado objetivo a ser alcançado ou uma decisão a ser tomada } \\
\text { (geralmente bem estruturada e específica). }\end{array}$ & $\begin{array}{l}\text { Determinado conjunto de meios (que geralmente consiste em características } \\
\text { circunstâncias relativamente inalteráveis do tomador de decisão). }\end{array}$ \\
\hline $\begin{array}{l}\text { Um conjunto de meios ou causas alternativas (que podem ser gerados a } \\
\text { partir do processo de decisão). }\end{array}$ & $\begin{array}{l}\text { Um conjunto de efeitos ou possíveis operacionalizações de aspiraçóes } \\
\text { generalizadas (geradas principalmente pelo processo de decisão). }\end{array}$ \\
\hline Restriçôes sobre possíveis meios (geralmente impostos pelo ambiente). & $\begin{array}{l}\text { Restriçóes e oportunidades para possíveis efeitos (geralmente impostos pelos } \\
\text { meios limitados, bem como pelo ambiente e suas contingências). }\end{array}$ \\
\hline $\begin{array}{l}\text { Critérios de seleçáa entre os meios (geralmente maximização do retorno } \\
\text { esperado). }\end{array}$ & $\begin{array}{l}\text { Critérios para selecionar entre os efeitos (geralmente um nível predeterminado } \\
\text { de perda acessível ou risco aceitável relacionado aos meios dados). }\end{array}$ \\
\hline
\end{tabular}

Nota. Fonte: Ferreira (2020, p. 42).

Para Sarasvathy (2003), “... o empreendedor eficaz começa com quem ele é, com o que ele sabe e com quem ele conhece, para descobrir pelo menos um cliente ou parceiro que esteja interessado em um produto ou serviço que possa oferecer" (Sarasvathy, 2003, p. 214). A autora sugere as seguintes indagaçôes: "dado o que sou, o que sei e quem conheço, o que posso fazer? Que tipos de efeitos posso criar?" (Sarasvathy \& Dew, 2005, p. 543).

Em suma, a análise do processo empreendedor a partir da lógica tradicional - ou causation - considera um resultado esperado para a ação empreendedora. O empreendedor, nesse caso, seleciona os meios disponíveis para obter tal resultado. Já na análise do processo empreendedor a partir da lógica effectuation, entende-se que o empreendedor detém um conjunto de meios e, assim, irá avaliar os possíveis efeitos que podem ser criados com esse determinado conjunto de meios (Sarasvathy, 2001).

Em outras palavras, a lógica effectuation não consiste em um processo de escolha entre alternativas dadas, mas em criar as próprias alternativas e, em conjunto, descobrir e avaliar qualidades desejáveis e indesejáveis de vários resultados possíveis. Isso significa, no modelo effectuation, que o empreendedor, nas suas decisóes, considera quatro princípios: (a) as perdas passíveis de serem aceitas; (b) as alianças necessárias para que incertezas sejam reduzidas; (c) a reflexáo sobre como melhor explorar as contingências; e (d) como administrar um futuro que, por sua natureza, é imprevisível (Sarasvathy, 2001; Sarasvathy, Forster, \& Ramesh, 2020).

Tabela 3. Princípios da teoria de effectuation.

\begin{tabular}{cl}
\hline Princípios & \multicolumn{1}{c}{ Características } \\
\hline $\begin{array}{c}\text { Custos de perdas } \\
\text { aceitáveis }\end{array}$ & $\begin{array}{l}\text { Consiste em testar todas as estratégias possíveis considerando os meios limitados que foram dados a partir da predeterminação } \\
\text { de o quanto a perda é aceitável. "O effectuator prefere escolhas que criam mais opçóes no futuro em detrimento daquelas que } \\
\text { maximizam os retornos no presente" (Sarasvathy, 2001, p. 252). }\end{array}$ \\
$\begin{array}{c}\text { Alianças estratégicas } \\
\text { Foco na formação de alianças estratégias com stakeholders de modo a reduzir e/ou eliminar a incerteza. "Os pré-compromissos dos } \\
\text { stakeholders tornam a incerteza irrelevante ao 'entregar' um futuro que parece muito semelhante ao que foi contratado" (Sarasvathy, } \\
\text { 2003, p. 210). }\end{array}$ \\
$\begin{array}{c}\text { Exploração de } \\
\text { contingências } \\
\begin{array}{c}\text { Controlar um futuro } \\
\text { imprevisível }\end{array}\end{array}$ & $\begin{array}{l}\text { Concentra-se em questôes do conflito de um futuro imprevisível. "Na medida em que podemos controlar o futuro, não precisamos } \\
\text { prevê-lo" (Sarasvathy, 2001, p. 252). }\end{array}$ \\
\hline
\end{tabular}

Nota. Fonte: Elaborado por Ferreira (2020) a partir de Sarasvathy (2001, p. 252). 
Considerando a teoria apresentada anteriormente, propóe-se:

a) Identifique e analise os momentos da trajetória empreendedora caracterizados por elementos tradicionais planejamento, avaliação, pesquisa -, embasando as decisôes do empreendedor e aqueles momentos identificados como sendo baseados na lógica effectuation.

b) Analise os princípios - custos de perdas aceitáveis, alianças estratégicas, exploração de contingências e controle do futuro imprevisível - utilizados pelo empreendedor na criação e trajetória da Facile. Em relação à Questão $1 \mathrm{~A}$ e considerando as informaçóes apresentadas no caso, destacam-se alguns eventos que ocorreram durante a trajetória empreendedora de Nilson e que podem ser compreendidos como açóes tomadas a partir da lógica do effectuation e outras por meio de planejamento (causation). Sob a lógica do effectuation, é possivel citar, por exemplo, a construçáo do relógio coador de café, que pode ser compreendido como o primeiro protótipo do produto que seria lançado no mercado nos anos seguintes. A partir da insatisfação em acordar cedo (quem sou eu), o invento, criado com materiais obtidos da escola onde Nilson estudava (o que eu sei? o que eu posso fazer?) teve o apoio da instituição ao submetê-lo e premiá-lo no evento científico do qual o aluno participara (interação com os stakeholders). Pela primeira vez, a instituição de ensino à qual Nilson estava vinculado the auxiliaria no desenvolvimento de suas ideias (comprometimento do stakeholder com o effectuation).

$\mathrm{O}$ interesse do jovem pela Engenharia o colocaria novamente em contato com as redes, mas agora na universidade. Foi dentro do campus universitário que Nilson arregimentou seu primeiro companheiro de trabalho, onde uniram as duas ideias para criarem o primeiro fervedor de água instantâneo. Suas relaçóes no Departamento de Engenharia, já como docente da universidade, lhe proporcionariam o acesso a uma infraestrutura onde pôde fabricar seu produto, momento em que iniciou a parceria com a MC Indústrias, em 1990. A empresa, que atuava como uma quase incubadora de empresas, proveu recursos valiosos a Nilson, inclusive no processo de patenteamento de sua invenção. Ainda nesse ínterim, aspectos da conjuntura econômica levaram ao encerramento da parceria. Devido a essa contingência, a Facile foi fundada, permitindo a continuação do processo empreendedor de Nilson.

Posteriormente, uma série de tentativas e erros e acertos - moldou o modelo de negócio da Facile. Por intermédio de relaçóes com a família e amigos, a empresa teve capacidade de se estruturar e se manter. Um amigo próximo, inclusive, foi a pessoa que o alertou de seu futuro problema com a obrigatoriedade de certificação no Inmetro. Os produtos que foram comercializados no período 2006-2012 foram fruto de operação familiar, tanto na fabricação quanto na venda boca a boca, além das vendas em feiras.
No caso das decisóes sob a lógica causation, podese identificá-las nos momentos em que o empreendedor se relacionou com parceiros que provariam ser agentes de desenvolvimento para o negócio e a empresa. Inicialmente, quando aindaem parceriacomaMCIndústria, o empreendedor teria acesso a diversos recursos para fortalecimento do negócio, incluindo pesquisas de mercado e reformulaçóes no design do produto para torná-lo mais competitivo. Processos de gestão assentados em práticas já estabelecidas por corpos teóricos e já experimentados por outras empresas podem ser considerados como de lógica causation. Da mesma forma, a entrada da empresa no processo de aceleração também pode ser reconhecida como de natureza causation. O próprio empreendedor considera que a profissionalização da empresa ocorreu a partir do ProTEC, quando substituiu práticas amadoras de gestáo. Processos organizados foram erigidos para negociação com clientes e fornecedores, assim como os processos de marketing e vendas. Além disso, o planejamento e a preparação para a conquista de certificação do Inmetro foram paralisados devido a uma contingência, o início da pandemia.

Em relação à Questão $1 \mathrm{~B}$, na qual serão analisados os quatro princípios do processo da lógica effectuation, propóemse os direcionamentos a seguir:

a) Custos de perdas aceitáveis: a decisão de Nilson por empreender enquanto tem um emprego fixo sugere que o empreendedor equilibra a estabilidade com o risco. A universidade, em vez de se tornar uma oposição ao seu desejo de empreender, acaba atuando de forma a auxiliar no desenvolvimento de suas ideias, principalmente pela rede de relaçóes e conhecimentos adquiridos nela. Além disso, o empresário parece disposto a investir com cautela em seu negócio, como na opção por não efetuar a certificação do Inmetro quando esta não era compulsória.

b) Alianças estratégicas: as alianças com parceiros permeiam toda a trajetória de Nilson como empreendedor, desde a concepçáo da empresa em parceria com outro inventor, a parceria com a MC Indústrias e o desenvolvimento do produto até as vendas realizadas em feiras e eventos e a posterior participação da empresa no processo de aceleração. Mais recentemente, pode mencionar-se a fabricaçáo do produto na planta industrial de um amigo. A realizaçáo do pré-teste de seu produto nos laboratórios da universidade demonstra como as alianças podem ser importantes para o desenvolvimento das novas ideias do empreendedor.

c) Exploração de contingências: a exploração de contingências mais recente que o empreendedor almeja é o aumento expressivo e perene do consumo de bebidas quentes no contexto nacional - principalmente o consumo de café no formato tradicional e gourmet - e a maior venda de eletroeletrônicos. Entretanto, outros momentos demonstraram que as contingências abrangem momentos 
de transição na empresa, como a mudança no cenário político-econômico do início da década de 1990 e o término da parceria com a MC Indústrias. Além disso, a decisão de Nilson em inscrever a empresa no programa de aceleraçáo realizado pela universidade representa exemplo de exploração de contingências.

d) Controlar um futuro imprevisível: a pandemia gera um futuro imprevisível na medida em que subverte comportamentos de clientes quanto aos seus hábitos de compra. Entretanto, a oportunidade de explorar um mercado de bebidas quentes, que exibe crescimento constante, parece ser uma tentativa de minimizar eventuais riscos. Além disso, a aposta no mercado de assinaturas blinda eventuais mudanças de comportamento dos futuros clientes, como a possibilidade de boicote a produtos eletrônicos não sustentáveis ou que tenham o processo de reciclagem com complexidade elevada.

Após a análise do processo empreendedor que permeia a trajetória do Nilson, a atividade seguinte coloca os olhos no presente, isto é, nos dilemas enfrentados pelo empreendedor durante o processo de aceleração e na própria pandemia que afetou sobremaneira as decisóes correntes.

Questáo 2 - Imagine-se no lugar de Márcio, o mentor de Nilson durante todo o programa de aceleração. Quais conselhos você daria a Nilson acerca do futuro da Faciletec? (35 minutos)

Nesse momento, propóe-se que os participantes se imaginem no lugar de Márcio, o mentor de Nilson, durante sua trajetória no ProTEC. A situação atual está posta: Nilson já separou os equipamentos para certificação do produto e a testagem com o serviço de assinatura está em vias de ocorrer. Com os dados levantados no corpo do caso, sugere-se que os alunos tracem recomendaçóes gerais que possam auxiliar Nilson após o fim do estado de pandemia.

Os questionamentos têm como objetivo introduzir os participantes no cargo de conselheiro e mentor. A partir dos dados apresentados, é desejável que os participantes os utilizem para fundamentar suas argumentaçôes. É interessante que o professor amplie a discussão com respostas distintas, mas que se mantenham calcadas nos dados apurados anteriormente.

Para geração das recomendaçóes, sugerem-se as seguintes questóes: $\mathrm{O}$ que muda com o novo cenário de COVID-19? A empresa deve mudar seus planos? Atrasá-los, cancelá-los? Ou seja, os testes devem ser mantidos, assim como a venda por meio das assinaturas? $\mathrm{O}$ que você faria se fosse o empreendedor responsável pela empresa nesse momento de incerteza? Após a pandemia, a Facile deveria rever as suas aspiraçóes (o que gostaria de se tornar)? Existe alguma alternativa criativa para a empresa utilizar nesse momento?

Em um contexto de dificuldades geradas pela pandemia, e considerando-se as características do produto e do modelo de negócio vigente, o processo de aceleraçáo desemboca em uma possibilidade de alteraçáo profunda no modelo de negócio da Faciletec. Essa é a questáo crítica a ser respondida na atividade seguinte.

Questão 3- Qual modelo de negócio deveria ser seguido pela Faciletec na venda de seu produto LigFerv? (85 minutos)

Essa questão foi proposta como uma discussão adicional às duas questóes anteriores, ficando a critério do professor - a depender da disponibilidade e maturidade das discussóes prévias - a sua realização. Conforme mencionado nas diretrizes abaixo, a tarefa une a perspectiva do processo empreendedor percorrido por Nilson com abordagens que tratam de modelos de negócios e estratégia.

O LigFerv iniciou o ano de 2020 envolto em diversos planos, muitos deles oriundos da participação no programa de aceleração. O ponto de partida foi a concepção de um novo modelo de negócio com base em assinatura mensal - fervedor em comodato e entrega mensal de café gourmet.

Apesar das diversas definições e modelos existentes, há consenso de que os modelos de negócios são utilizados para a representação de como os empreendimentos realizam suas operações de forma dinâmica (Andreini \& Bettinelli, 2017; Osterwalder \& Pigneur, 2003), combinando os recursos existentes para gerar valor ao cliente e também para a organizaçáo (DaSilva \& Trkman, 2014). Um dos modelos para a construção de modelos de negócio é o Business Model Canvas (Osterwalder \& Pigneur, 2010), adequado para estudos em disciplinas de natureza prática (Andreini \& Bettinelli, 2017). $\mathrm{O}$ quadro - canvas - que delimita o desenvolvimento do modelo de negócio é subdividido em nove blocos: (a) segmentos de mercado; (b) proposta de valor; (c) canais; (d) relação com o cliente; (e) fontes de receita; (f) recursoschave; (g) atividades-chave; (h) parceiros-chave; e, por fim, (i) estrutura de custos.

Sugere-se então uma subdivisão dos alunos em três grupos distintos - passível de adaptação conforme o número de alunos em sala de aula - para reflexáo e definição de um modelo de negócios baseado no modelo canvas. Recomendase iniciar a atividade com a discussão sobre qual(is) será(ão) a(s) proposta(s) de valor que orientará(ão) a elaboração do modelo de negócio para a Faciletec/LigFerv. Posteriormente, para cada grupo, parte do modelo poderá ser indicada: (a) segmentos de mercado, relaçáo com o cliente e canais; (b) recursos principais, atividades-chave e parceiros-chave; (c) estrutura de custos e fontes de receita.

Ressalta-se que, uma vez que as empresas buscam a utilização das tecnologias de informação e comunicação para desenvolvimento de seus negócios, é comum que novas e complexas proposiçóes de valor surjam, juntamente com grande quantidade de possíveis canais de distribuição. $\mathrm{O}$ aumento da complexidade do modelo acaba refletido no 
valor gerado pelo modelo de negócio, estando em função também do desempenho da atuação de stakeholders externos, como fornecedores e parceiros que atuam na distribuição (Osterwalder \& Pigneur, 2003).

Entretanto, a oportunidade de desenvolver um modelo de negócio traz consigo questionamentos importantes que podem ser aprofundados pelo instrutor. Sendo assim, antes mesmo da construçáo do modelo, uma forma de enriquecer a criação do modelo pelos alunos e fomentar o debate é a discussão sobre a diferença entre dois conceitos que usualmente são tomados como sinônimos: modelo de negócio e estratégia (DaSilva \& Trkman, 2014; Teece, 2017). A diferença entre ambos parte de uma premissa temporal. Enquanto a estratégia reflete o que uma empresa gostaria de ser, o modelo de negócio descreve o que a organização definitivamente é naquele espaço de tempo (DaSilva \& Trkman, 2014; Teece, 2017). Para tanto, propóe-se que o grupo de alunos inicie a tarefa de construção do quadro após responder a questóes como: "Qual(is) será(ão) a(s) estratégia(s) da Faciletec?"; "Em que a Faciletec gostaria de se tornar?", "Quais são as capacidades da organização, ou seja, quais recursos ela possui para construir, testar e revisar o modelo de negócio que iremos planejar?”

Como exemplo, é possível citar a economia de assinatura, que existe há algum tempo, mas se expandiu com o avanço das formas digitais de consumo (Citi, 2020). Nesse ambiente de trocas, encontramos os atores que popularizaram o termo - e o negócio -, como as empresas de streaming de vídeo e de música, assim como as de jogos digitais, mas também se encontram pequenos negócios, que buscam usufruir das vantagens da economia por assinatura. Entre elas estão mais previsibilidade nas projeçóes de receita, o contato direto com o cliente, e economias de escala, dado que os custos fixos são relativamente baixos (Zuora, 2019).

No Brasil, um dos modelos de assinatura que ganharam popularidade nos anos 2010 foram os clubes de assinatura, mercado que já conta com mais de 800 empresas, com faturamento de cerca de $\mathrm{R} \$ 1$ bilhão no ano de 2018 (Simôes, 2019). Esses clubes são, na maior parte das vezes, distribuídos em duas vertentes. Uma delas atua na entrega de produtos recorrentes, que hoje respondem por ampla gama de produtos, desde ração para pets a lâminas de barbear. A outra atua na entrega de produtos por meio da curadoria de especialistas, como vinhos e livros (Associação Brasileira de Comércio Eletrônico, 2017).

A partir das medidas restritivas de circulação devido à pandemia de COVID-19, pequenos negócios, ao embarcarem nos mecanismos de venda digitais, também começaram a flertar com a economia de assinatura (Barbo, 2020). São empresas que tentam usufruir da tendência de pagamentos facilitados e recorrentes, como as compras de cartão de crédito a distância, que alcançaram o valor de $\mathrm{R} \$ 86,7$ bilhóes no primeiro trimestre de 2020 , aumento de $23,2 \%$ em relação a 2019 (Albuquerque, 2020).

A seguir, encontra-se uma proposta de quadro inicial com o modelo de negócio estruturado pela Faciletec até o momento de sua entrada no programa de aceleração. As interrogaçóes sugerem possíveis oportunidades que foram discutidas durante as mentorias e ainda não estariam sendo exploradas.

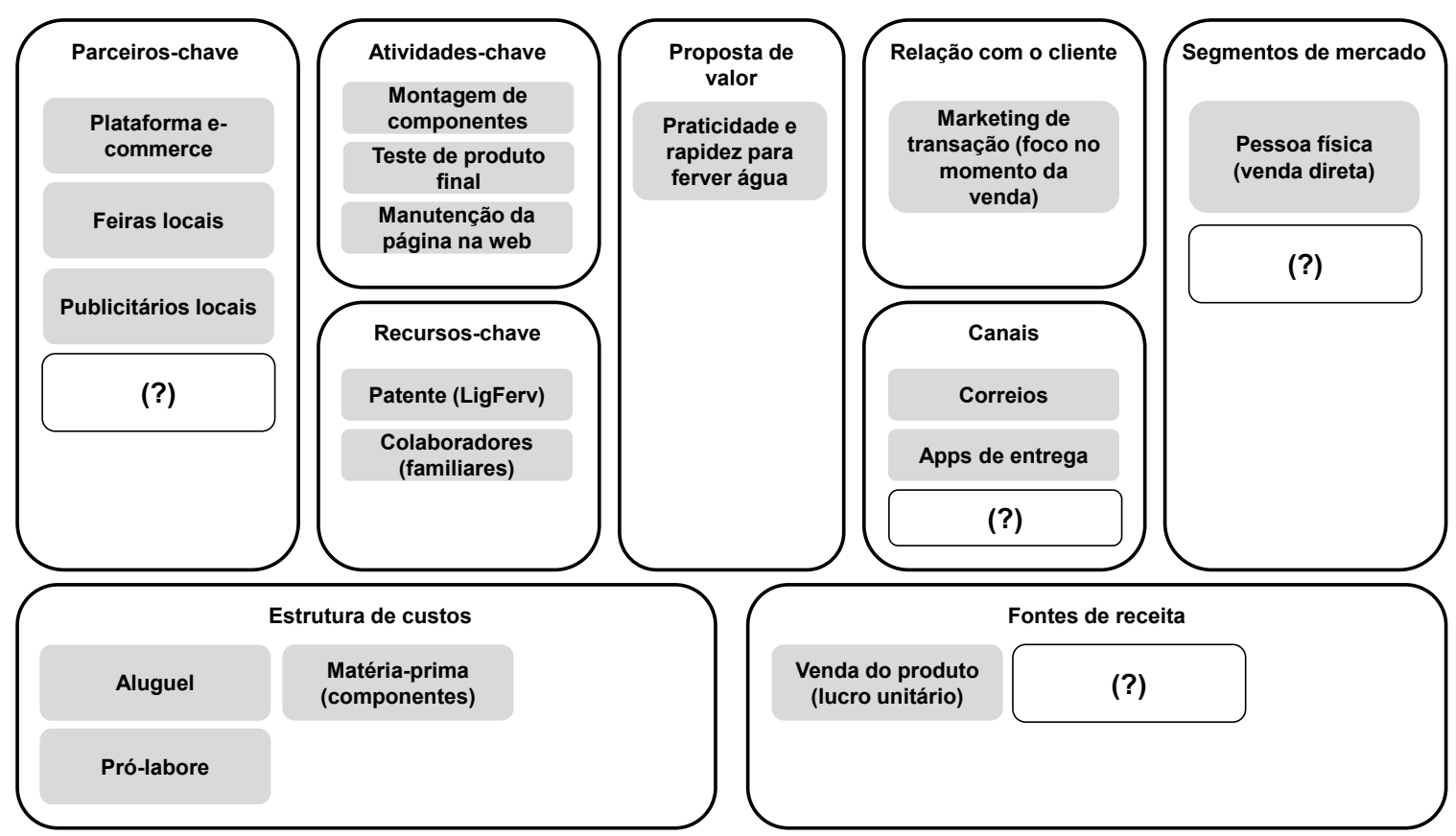

Figura 6. Proposta de quadro inicial para a Faciletec (2006-2018). 


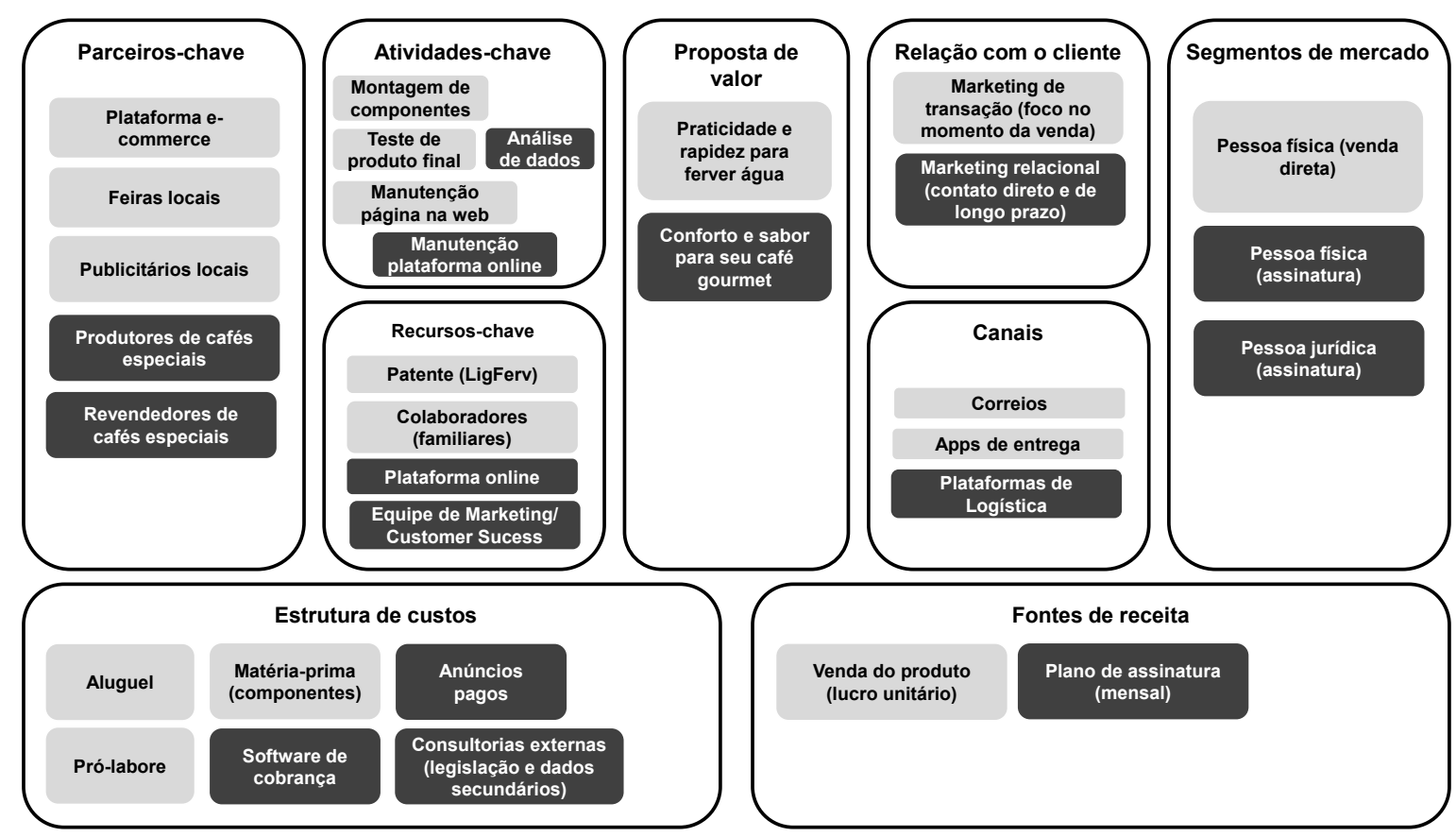

Figura 7. Proposta de quadro integrado para a Faciletec (2018).

\section{REFERÊNCIAS}

Albuquerque, F. (2020, May). Compras com cartões crescem 14,1\% no primeiro trimestre, diz Abecs. Agência Brasil. Retrieved from https://agenciabrasil.ebc.com.br/economia/ noticia/2020-05/compras-com-cartoes-crescem-141-noprimeiro-trimestre-diz-abecs\#: - :text=Levantamento $\% 20$ feito $\% 20$ pela $\% 20$ Associa $\% \mathrm{C} 3 \% \mathrm{~A} 7 \% \mathrm{C} 3 \% \mathrm{~A} 3 \mathrm{o} \% 20$ Brasileira, R\%24\%20475\%2C7\%20bilh\%C3\%B5es

Andreini, D., \& Bettinelli, C. (2017). Business model innovation: From systematic literature review to future research directions. Cham, Switzerland: Springer.

Associação Brasileira de Comércio Eletrônico (2017, February). Clubes de assinatura aproximam clientes. Retrieved from https://abcommsc.com.br/2017/02/08/clubes-de-assinaturaaproximam-clientes/

Barbo, L. (2020, April). Clubes de assinatura podem ser alternativa para minimizar a crise. Jornal de Brasilia. Retrieved from https://jornaldebrasilia.com.br/gastronomia/lu-barbo/ clubes-de-assinatura-podem-ser-alternativa-para-minimizara-crise/

Bourry, E. C. M. S., \& Teixeira, A. C. C. (2019). Effectuation logic. Revista de Empreendedorismo e Inovação Sustentáveis, 4(1), 64-80. Retrieved from http://revista.isaebrasil.com.br/ index.php/EGS/article/view/30
Citi (2020). Signing up to the subscription economy: The race for recurring revenue in Asia Pacific. Retrieved from https://www.citibank.com/tts/insights/articles/article81.html

DaSilva, C. M., \& Trkman, P. (2014). Business model: What it is and what it is not. Long Range Planning, 47(6), 379-389. https://doi.org/10.1016/j.lrp.2013.08.004

Feger, J. E., Vieira, R. S., \& Chemin, M. (2016). Relação entre as características centrais empreendedoras e o processo de criação de empresas: um estudo exploratório. Revista de Administração, Contabilidade e Economia, 15(3), 10351064. http://dx.doi.org/10.18593/race.v15i3.8875

Ferreira, K. F. O. (2020). Análise do processo empreendedor a partir das lógicas effectuation e causation: Um estudo de caso em duas empresas mineiras (Master Thesis). Pontifícia Universidade Católica de Minas Gerais, Belo Horizonte, MG, Brazil. Retrieved from http://www.biblioteca.pucminas.br/teses/ Administracao KarinaFernandaOliveiraFerreira 8559.pdf

Hisrich, R. D., Peters, M. P., \& Shepherd, D. A. (2014). Empreendedorismo (9. ed.). Porto Alegre: Amgh Editora.

Osterwalder, A., \& Pigneur, Y. (2003). An ontology for e-business models. In W. L. Currie (Ed.), Value creation from e-business models (p. 65-97). Oxford, UK: Butterworth-Heinemann. https://doi.org/10.1016/B978-0-7506-6140-9.X5000-0 
Osterwalder, A., \& Pigneur, Y. (2010). Business model generation: $A$ handbook for visionaries, game changers, and challengers. New Jersey: Wiley.

Sarasvathy, S. D. (2001). Causation and effectuation: Toward a theoretical shift from economic inevitability to entrepreneurial contingency. Academy of Management Review, 26(2), 243-263. https://doi.org/10.5465/amr.2001.4378020

Sarasvathy, S. D. (2003). Entrepreneurship as a science of the artificial. Journal of Economic Psychology, 24(2), 203-220. https://doi.org/10.1016/S0167-4870(02)00203-9

Sarasvathy, S. D., \& Dew, N. (2005). New market creation through transformation. Journal of Evolutionary Economics, 15, 533-565. https://doi.org/10.1007/s00191-005-0264-x
Sarasvathy, S. D., Forster, W., \& Ramesh, A. (2020). From Goldilocks to Gump: Entrepreneurial mechanisms for everyday entrepreneurs. REGEPE - Revista de Empreendedorismo e Gestão de Pequenas Empresas, 9(1), 189-220. http://dx.doi.org/10.14211/regepe.v9i1.1803

Simões, K. (2019). Clubes de assinatura já faturam mais de $\mathrm{R} \$ 1$ bi. Valor Econômico. Retrieved from https://valor.globo.com/ publicacoes/suplementos/noticia/2019/11/29/clubes-deassinatura-ja-faturam-mais-de-r-1-bi.ghtml

Teece, D. J. (2017). Business models and dynamic capabilities. Long Range Planning, 51(1), 40-49. https://doi.org/10.1016/j.lrp.2017.06.007

Zuora (2019). Subscription economy index. Retrieved from https:// www.zuora.com/resource/ subscription-economy-index/ 


\section{Autoria}

\section{João Paulo Moreira Silva}

Pontifícia Universidade Católica de Minas Gerais, Programa de Pós-graduação em Administração

Av. Itaú, no 525, Dom Cabral, 30535-012, Belo Horizonte, MG, Brasil.

E-mail: joao.msilva@live.com

(1) https://orcid.org/0000-0002-9470-2905

\section{Liliane de Oliveira Guimarães*}

Pontifícia Universidade Católica de Minas Gerais, Programa de Pós-graduação em Administração

Av. Itaú, no 525, Dom Cabral, 30535-012, Belo Horizonte, MG, Brasil.

E-mail: lilianeog@pucminas.br

(1) https://orcid.org/0000-0002-3346-2207

\section{José Márcio de Castro}

Pontifícia Universidade Católica de Minas Gerais, Programa de Pós-graduação em Administração

Av. Itaú, no 525, Dom Cabral, 30535-012, Belo Horizonte, MG, Brasil.

E-mail: josemarcio@pucminas.br

(1) https://orcid.org/0000-0002-3170-9456

* Autora Correspondente

\section{Financiamento}

Os autores agradecem à Fundaçáo de Amparo à Pesquisa do Estado de Minas Gerais (FAPEMIG) pelo suporte financeiro para a pesquisa deste artigo.

\section{Conflito de Interesses}

Os autores informaram que não há conflito de interesses.

\section{Verificação de Plágio}

A RAC mantém a prática de submeter todos os documentos aprovados para publicação à verificação de plágio, mediante o emprego de ferramentas específicas, e.g.: iThenticate.

\section{Contribuições dos Autores}

$1^{\text {o }}$ autor: conceitualização (igual); investigação (igual); metodologia (igual); visualização (igual); redação - rascunho original; redação - revisão e edição (igual).

$2^{a}$ autora: conceitualização (líder); investigaçáo (igual); metodologia (igual); administração do projeto (igual); supervisão (igual); visualização (igual); redação - revisão e ediçãoo (líder).

$3^{0}$ autor: conceitualização (igual); investigação (igual); metodologia (igual); administraçáo do projeto (igual); supervisão (igual); redação - revisão e edição (igual).

\section{Direitos Autorais}

A RAC detém os direitos autorais deste conteúdo.

\section{Método de Revisão por Pares}

Este conteúdo foi avaliado utilizando o processo de revisão por pares duplo-cego (double-blind peer-review). A divulgação das informaçóes dos pareceristas constantes na primeira página é feita somente após a conclusão do processo avaliativo, e com o consentimento voluntário dos respectivos pareceristas

\section{Disponibilidade dos Dados}

Todos os dados e materiais foram disponibilizados publicamente por meio da plataforma Harvard Dataverse e podem ser acessados em:

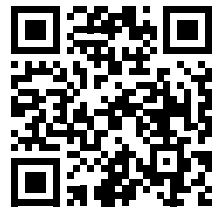

João Paulo Moreira Silva; Liliane de Oliveira Guimarães; José Márcio de Castro, 2021, "Replication Data for: "Facile/LigFerv: Hot water in three seconds, thirty years of entrepreneurial process"'", Harvard Dataverse, V1. https://doi.org/10.7910/DVN/PHRAKH

A RAC incentiva o compartilhamento de dados mas, por observância a ditames éticos, não demanda a divulgaçáo de qualquer meio de identificação de sujeitos de pesquisa, preservando a privacidade dos sujeitos de pesquisa. A prática de open data é viabilizar a reproducibilidade de resultados, e assegurar a irrestrita transparência dos resultados da pesquisa publicada, sem que seja demandada a identidade de sujeitos de pesquisa. 


\section{APÊNDICE A.}

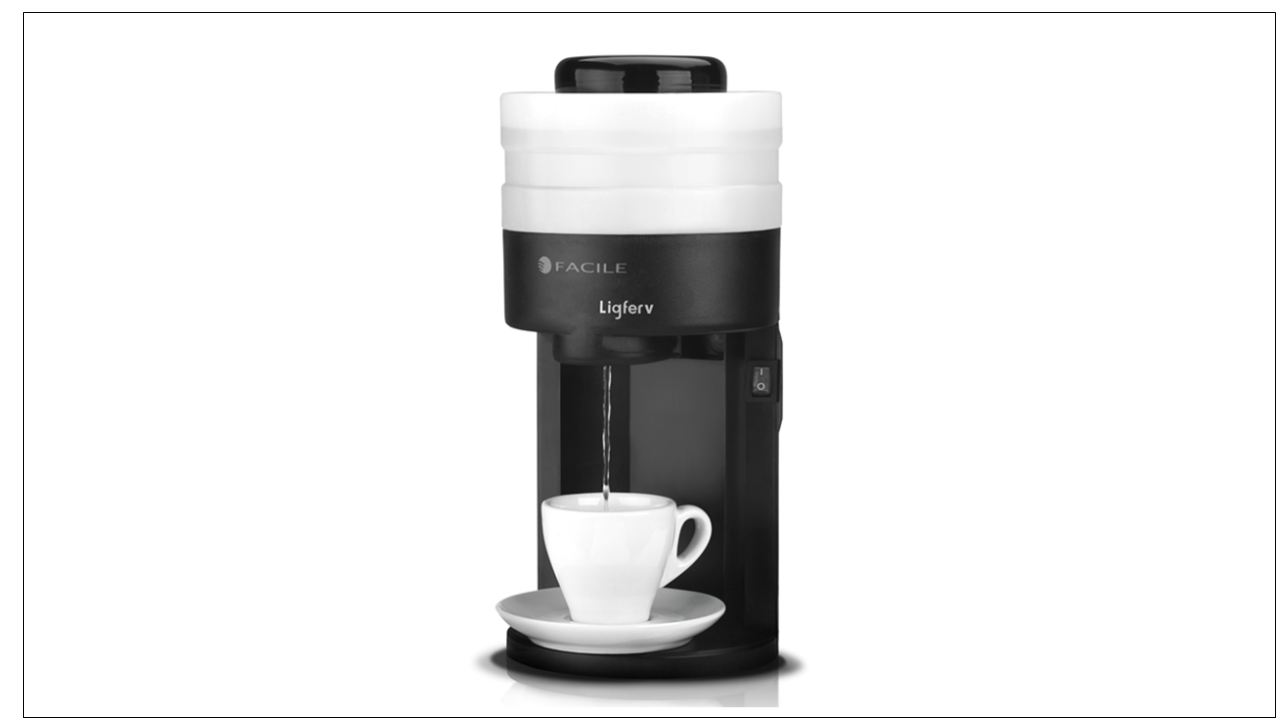

Figura A1. Modelo atual - LigFerv.

Fonte: Foto fornecida pelo empreendedor entrevistado.

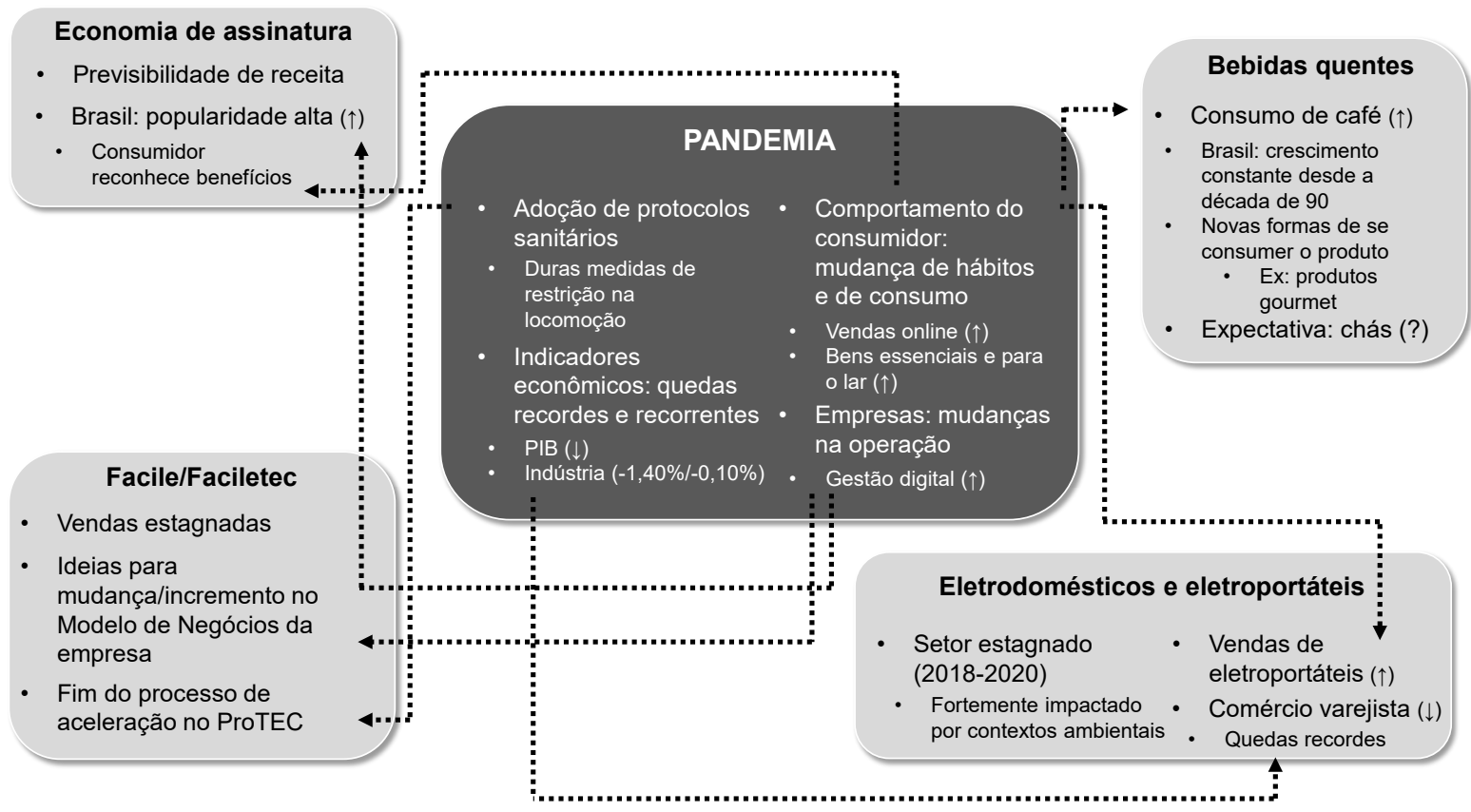

Figura A2. Esquema geral proposto para discussão plenária. Fonte: Elaborado pelos autores. 